\title{
Editorial: diversity of marine meiofauna on the coast of Brazil
}

\author{
Gustavo Fonseca • Jon Norenburg • \\ Maikon Di Domenico
}

Received: 25 June 2014 /Revised: 16 July 2014 / Accepted: 4 August 2014 / Published online: 20 August 2014

(C) Senckenberg Gesellschaft für Naturforschung and Springer-Verlag Berlin Heidelberg 2014

\begin{abstract}
After a first bout of primarily taxonomical effort, meiofauna studies in Brazilian waters remained virtually neglected until the 1990s. At the end of the last century, taxonomical and ecological studies on meiofauna taxa were again published regularly, especially for Nematoda and Copepoda. In this issue, 18 new species are described and ten species are redescribed from seven Phyla. The five ecological articles cover the spatial distribution of forams and amoeba in a lagunar system, the meiofauna associated with biogenic structures, the relationship between nematodes and granulometry, and the response of sandy-beach meiofauna to a natural, shortterm pulse of diatoms. All these contributions show the potential of the Brazilian coast for revealing new species and testing small to large-scale hypotheses about ecological processes.
\end{abstract}

Keywords Brazil $\cdot$ Ecology $\cdot$ Marine $\cdot$ Meiofauna $\cdot$ New species $\cdot$ Taxonomy

The main objectives of this editorial are to share the motivation that led us to organize this special issue and summarize the major findings of each article. Thus, instead of organizing an extensive literature review on the topic, we give an overview of

\footnotetext{
G. Fonseca $(\bowtie)$

Departamento de Ciências do Mar, Universidade Federal de São Paulo, Av. Alm Saldanha da Gama 89, Santos, SP 11030-400, Brazil e-mail: gfonseca@unifesp.br

J. Norenburg

Department of Invertebrate Zoology, Smithsonian National Museum of Natural History, Washington, DC 20560, USA

\section{Di Domenico}

Zoological Museum "Prof. Dr. Adão José Cardoso", Biological Institute, University of Campinas (UNICAMP), R Charles Darwin s/n, Bloco N, P.O. Box 6109, 13083-863 Campinas, SP, Brazil e-mail: maik2dd@gmail.com
}

the progress of marine meiofauna studies at the Brazilian coast using key researchers and publications as examples.

The diversity of meiofauna taxa on the Brazilian coast has been investigated since the beginning of the last century (e.g. Cobb 1920). Early studies were points in space and time, and were devoted to the description of new species. In the middle of the last century (1940-60) there was a sudden increase in the number of meiofauna studies worldwide. In Brazil, this was led by the prolific meiofaunal species descriptions and systematic reviews of Ernest Marcus and Eveline du Bois-Reymond Marcus (Medeiros 1987; Corrêa 1991). Together they published more than 220 scientific papers. Considering only the marine meiofauna, they described an enormous number of species and genera belonging to Platyhelminthes (Proseriata and Rhabdocoela), Acoela (formerly included in Platyhelminthes), Mollusca (Opisthobranchia), Tardigrada, and Annelida (including polychaetes and oligochaetes) (e.g. Du Bois-Reymond 1943; 1946; 1947; 1948; 1950; 1953; 1955; 1957; 1958; Marcus 1946, 1947; Marcus and Du Bois-Reymond 1951; 1954a; 1954b; 1955; 1956; 1957). Diva Diñiz Corrêa, a former student and subsequent colleague of Ernest and Eveline Marcus, published several papers on the taxonomy of Ototyphlonemertes (Nemertea) (Corrêa 1948, 1949, 1950, 1953, 1957) and was for many years the leading authority on the group. During the same period, there was a series of papers by foreign researchers on specific taxonomic groups of Brazilian meiofauna, such as Nematoda (Gerlach 1954, 1957; Meyl 1956), Kinorhyncha (Gerlach 1956), Isopoda (Remane and Siewing 1953), Amphipoda (Siewing 1953), Harpacticoida (Jakobi 1953; Jakobi 1954; Jakobi and Loyola e Silva 1962), Acari (Schuster 1962), Ostracoda (Hartmann 1955, 1956), and Annelida (Siewing 1954; Gerlach and Siewing 1956; Westheide 1974).

After this first bout of primarily taxonomical effort, meiofauna studies remained virtually neglected in Brazilian waters until the 1990s. In the end of the last century taxonomical 
Fig. 1 Citation metrics retrieved from Google Scholar using the terms "meiofauna" or "meiobenthos" and further refining for country "Brazil": a) number of publications per year; b) number of citations per year a

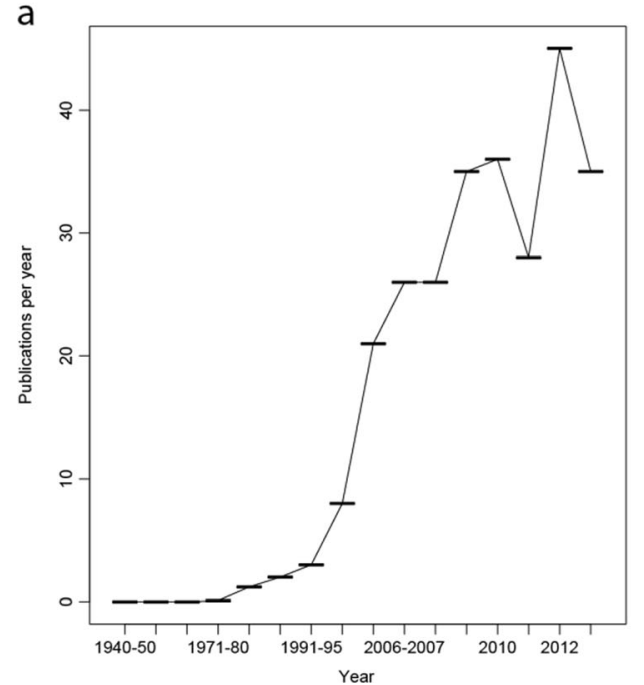

b

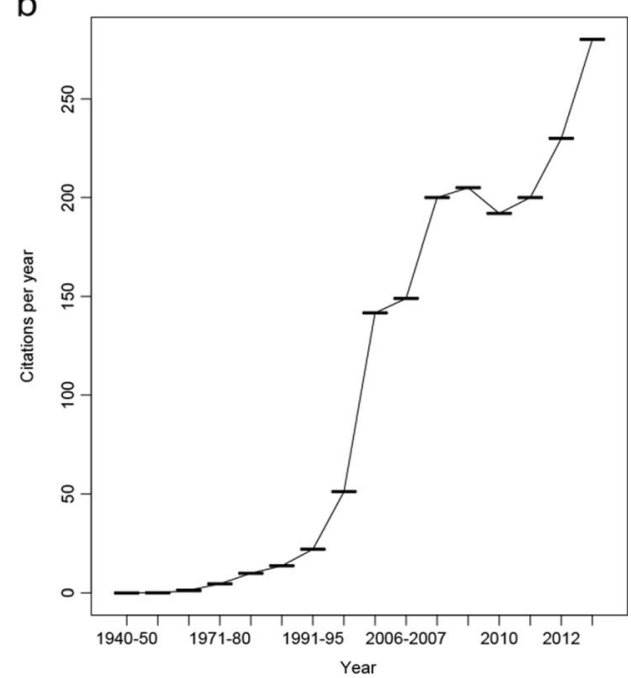

and ecological studies on meiofauna taxa again were published regularly(e.g. Todaro \& Rocha 2004, 2005, Hooge \& Rocha 2006, Amaral \& Nalin 2011, Andrade et al. 2011, Dal Zotto et al. 2013), especially for Nematoda and Copepoda (Carvalho et al. 1992; Corbisier 1993, 1999; Esteves et al. 1997; Esteves and Genevois 1997; Genevois and Bezerra 1997; Kihara and Rocha 2009; Lotufo and Rocha 1993; Netto et al. 1999a, b; Santos et al. 1999). According to the ISI Web of Knowledge and Google Scholar, it is only in the last decade that publications on meiofauna by Brazilian authors have been published consistently every year among ISI journals as well as in "gray" literature (Fig. 1a). Today Brazilian production of meiofauna studies is still modest, up to 14 articles/year amongst ISI journals and around 40 articles/year amongst all literature (Google Scholar), but the number of citations is doubling every four years (Fig. 1b), which is aided by increasing electronic searches and access to literature in the last decades.

It should be noted that much of the taxonomical work was focused on the southeastern coast of Brazil, and especially the state of São Paulo. Given the extensive and very heterogeneous coastline shaped by mangroves, salt marshes, exposed and protected sandy beaches, bays, estuaries, rocky shores, coral reefs, islands, and an extensive continental shelf, the Brazilian coast has tremendous potential for revealing new species and testing small- to large-scale hypothesis about ecological processes. Brazilian researchers still are in the beginning stages of this endeavour and continue to benefit significantly from international collaborations and expertise, especially in view of the global deficit of taxonomic expertise for meiofauna. In order to promote such an exchange between Brazilian and international researchers, the workshop "Taxonomy and diversity of marine meiofauna - Brazil" was organized in October 2012 . The workshop was very successful and nine articles in this special issue are from material collected during this event. The other six articles are contributions of individual researchers. The articles in this special issue cover two major themes: taxonomy and ecology of meiofauna.

\section{Taxonomy}

In this issue there are ten taxonomical articles covering seven distinct major taxa: Gastrotricha (Hochberg 2014; Araújo et al. 2014), Kinorhyncha (Sørensen 2014), Nematoda (Bezerra et al.
Table 1 Number of new and redescribed species ( $\mathrm{N}$ sp.) in this special issue

\begin{tabular}{llll}
\hline & Taxon & N sp. & Reference \\
\hline New species & Gastrotricha & 2 & Araújo et al. 2014; Hochberg 2014 \\
& Kinorhyncha & 3 & Sørensen 2014 \\
& Nematoda & 2 & Bezerra et al. 2014 \\
& Platyhelminthes: Proseriata & 9 & Curini-Galetti 2014 \\
& Rhadbocoela & 2 & Reygel et al. 2014 \\
Re-description & Mollusca: Gastropoda & 1 & Jörger et al. 2014 \\
& Platyhelminthes: Proseriata & 7 & Curini-Galetti 2014 \\
& Annelida: Polychaeta & 2 & Di Domenico et al. 2014 \\
\hline
\end{tabular}


2014; Venekey et al. 2014), Oligochaeta (Prantoni et al. 2014), Polychaeta (Di Domenico et al. 2014), Platyhelminthes (CuriniGaletti 2014; Reygel et al. 2014), and Mollusca (Jörger et al. 2014). In total, 18 new species are described and 10 species are re-described (Table 1). Additionally, Prantoni et al. give an updated list of valid oligochate species for the Brazilian coast, and Venekey et al. make a detailed review at the species level on a typical marine nematode family, the Xyalidae. In this study Venekey et al. also present a list of nematode species registered along the Brazilian coast and a brief discussion on the types of habitat in which Xyalidae species occur.

\section{Ecology}

Among the five ecological articles, one article deals with foraminifera and amoeba from lagunar systems composed of several interconnected lagoons (Leipniz et al. 2014). Although the whole system is connected, they showed that each lagoon has a particular set of species, regulated by a different set of environmental factors. Two articles deal with the underexplored field of meiofauna associated with biogeneic structures. Corrêa et al. (2014) describe the macro- and meiofauna associated with carapaces of sea turtles and conjecture on potential ecological processes structuring these associations. Ataide et al. (2014) describe the particularities of the fauna associated with sandy reefs built by the polychaete Sabellaria. Both studies show that biogenic structures are characterized by specific meiofauna taxa.

Two studies have an experimental design. Fonseca et al. (2014) test specifically whether nematode species richness increases with sediment mean grain size. They reject this hypothesis and show that along the sediment spectrum, each genus has a distinct optimum distribution at a relative narrow grain size. Netto and Meneghel (2014) tested the response of sandy beach meiofaunal organisms to a natural short-term (1 day) pulse of diatoms. They observed a simultaneous increase of meiofauna organisms inhabiting the intertidal zone, where most of the diatoms accumulated, and a subsequent decrease. The proposed mechanism is that sandy beach meiofauna is very mobile, enabling it to rapidly use this one-day window of opportunity.

Acknowledgments We are grateful for the financial support given by FAPESP (2011/28293-0) and for Marcus Martinez from Carl Zeiss Brazil for providing us with high quality optical devices and technical support during the workshop. São Paulo Research Foundation (FAPESPProcess 2012/08581-0; 2013/04358-7) also provided postdoctoral fellowships and grants for MDD. We are also thankful for Pedro Martinez, the editor in chief of Marine Biodiversity, for encouraging this issue.

\section{References}

Amaral ACZ, Nalin SAH (2011) Biodiversidade e ecossistemas bentônicos marinhos do Litoral Norte de São Paulo, Sudeste do
Brasil. Campinas, SP: UNICAMP/IB. ISBN (e-book): 978-8585783-24-2. 573p

Andrade SCS, Norenburg JL, Solferini VN (2011) Worms without borders: genetic diversity patterns in four Brazilian Ototyphlonemertes species (Nemertea, Hoplonemertea). Mar Biol 158(9):2109-2124

Araújo TQ, Balsamo M, Garraffoni ARS (2014) A new species of Pseudostomodella (Gastrotricha, Thaumastodermatidae) from Brazil. Mar Biodivers. doi:10.1007/s12526-013-0196-x

Ataide MB, Venekey V, Rosa-Filho JS, Dos Santos PJP (2014) Sandy reefs of Sabellaria wilsoni (Polychaeta - Sabellariidae) as ecosystem engineers for meiofauna in the Amazon coastal region. Braz Mar Biodivers. doi:10.1007/s12526-014-0248-x

Bezerra T, Smol N, Vincx M (2014) Two new species of Rhynchonema Cobb, 1920 from a Brazilian sandy beach. Mar Biodivers. doi:10. 1007/s12526-014-0223-6

Carvalho IB, Genevois VGF, Genevois B (1992) Heterogeneidade espaço-temporal da meiofauna na Baía de Tamandaré-Pernambuco, Brasil. Biol Bras 4:43-56

Cobb NA (1920) One hundred new nemas (type species of one hundred new species). Contrib Sci Nematol 9:217-343

Corbisier TN (1993) Meiofauna da plataforma continental interna do litoral norte de Sao Paulo - Verao/89. Publ Especial Inst Oceanogr 10:123-135

Corbisier TN (1999) Filo Nematoda. In: Joly CA, Bicudo CEM (Eds) Biodiversidade do Estado de São Paulo, Brasil: Síntese do Conhecimento ao Final do Século XX. 1ed. São Paulo: FAPESP p $113-122$

Corrêa DD (1948) Ototyphlonemertes from Brazilian Coast. Comun Zool Mus Hist Nat Montev 2(49):1-12

Corrêa DD (1949) Ecological studies of Brazilian Ototyphlonemertes. Commun Zool Mus Hist Nat Montev 3:1-7

Corrêa DD (1950) Sobre Ototyphlonemertes do Brasil. Bol Fac Filos Ciên Let Univ Sao Paulo (Zool) 15:203-234

Corrêa DD (1953) Sobre a neurofisiologia locomotora de Hoplonemertinos e a taxonomia de Ototyphlonemertes. An Acad Bras Ciências 25: $545-555$

Corrêa DD (1957) Nemertinos do litoral brasileiro (VI). An Acad Bras Ciências 29:251-271

Corrêa DD (1991) Dr. Eveline du Bois-Reymond Marcus. Hydrobiologia 227:23-26

Corrêa GVV, Ingels J, Valdes YV, Fonsêca-Genevois VG, Farrapeira CMR, Santos GAP (2014) Diversity and composition of macroand meiofaunal carapace epibionts of the hawksbill sea turtle (Eretmochelys imbricata Linnaeus, 1822) in Atlantic waters. Mar Biodivers. doi:10.1007/s12526-013-0189-9

Curini-Galetti M (2014) Contribution to the knowledge of the Proseriata (Platyhelminthes: Rhabditophora) from southeast Brazil. Mar Biodivers. doi:10.1007/s12526-014-0216-5

Dal Zotto M, Di Domenico M, Garaffoni A, Sørensen MV (2013) Franciscideres gen. nov.- a new, highly aberrant kinorhynch genus from Brazil, with an analysis of its phylogenetic position. Syst Biodivers. doi:10.1080/14772000.2013.819045

Di Domenico M, Martínez A, Amaral ACZ, Lana PC, Worsaae K (2014) Saccocirridae (Annelida) from the southern and southeastern Brazilian coasts. Mar Biodivers. doi:10.1007/s12526014-0208-5

Du Bois-Reymond ME (1943) Sobre Tardigrados Brasileiros. Comun Zool Mus Hist Nat Montev 1(13):1-20

Du Bois-Reymond ME (1946) On a new archiannelid, Saccocirrus gabriellae. Comun Zool Mus Hist Nat Montev 2(37):1-6

Du Bois-Reymond ME (1947) Nerilla mediterranea from Brazil. Comun Zool Mus Hist Nat Montev 2(45):1-6

Du Bois-Reymond ME (1948) Further archiannelids from Brazil. Comun Zool Mus Hist Nat Montev 2(48):1-17

Du Bois-Reymond ME (1950) A marine tubificid from Brazil. Comun Zool Mus Hist Nat Montev 3(59):1-6 
Du Bois-Reymond ME (1953) The opisthobranch Pseudovermis. Bol Fac Filos Ciên Univ Sao Paulo (Zool) 18:109-127

Du Bois-Reymond ME (1955) On Turbellaria and Polygordius from the Brazilian coast. Bol Fac Filos Ciên Letr Univ Sao Paulo (Zool) 20: $19-53$

Du Bois-Reymond ME (1957) On Turbellaria. An Acad Bras Cienc 29: 153-191

Du Bois-Reymond ME (1958) On South American Turbellaria. An Acad Bras Cienc 30:391-417

Esteves AM, Genevois VF (1997) Microdistribuição da meiofauna na Coroa do Avião, Pernambuco-Brasil, com referência especial a utilização de análise de autocorrelação espacial. Braz Arch Biol Technol 40:89-95

Esteves AM, Absaslão RS, Silva VMAP (1997) The importance of costeffectiveness sampling in the study of intertidal sandy beach meiofauna. Trop Ecol 38:47-53

Fonseca G, Maria TF, Kandratavicious N, Venekey V, Gheller PF, Gallucci F (2014) Testing for nematode-granulometry relationships. Mar Biodivers. doi:10.1007/s12526-014-0241-4

Genevois VF, Bezerra TNC (1997) Distribuição espaço-temporária da meiofauna nas águas intersticiais de Olinda-PE. Biol Bras 7:85-102

Gerlach S-A (1954) Brasilianische Meeres-Nematoden. Bol Inst Oceanogr Sao Paulo 5:3-69

Gerlach S-A (1956) Über einen aberranten Vertreter der Kinorhynchen aus dem Küstengrundwasser. Kiel Meeresforsch 12:120-124

Gerlach S-A (1957) Die Nematodenfauna des Sandstrandes and der Küste von Mittelbrasilien. Mitt Zool Mus Berlin 33:411-459

Gerlach S-A, Siewing R (1956) A Bathynellid from the New World. Nature 177:289

Hartmann G (1955) Neue marine Ostracoden der Familie Cypridae und der Sub-Familie Cytherideinae der Familie Cytheridae aus Brasilien. Zool Anz 154:109-127

Hartmann G (1956) Weitere neue marine Ostracoden aus Brasilien. Beitr Neotropical Fauna 1:19-62

Hochberg R (2014) Crasiella fonseci, a new species of Gastrotricha (Macrodasyida, Planodasyidae) from São Paulo, Brazil. Mar Biodivers. doi:10.1007/s12526-013-0165-4

Hooge MD, Rocha CEF (2006) Acoela (Acoelomorpha) from the northern beaches of the state of Sao Paulo, Brazil, and a systematic revision of the family Otocelididae. Zootaxa 1335:1-50

Jakobi H (1953) Neue Tegastiden (Hapacticoidea - Copepoda) von der Küste Santa Catarina (Brasilien). Dusenia 4:47-60

Jakobi H (1954) Harpacticoida (Cop. Crust.) da microfauna do substrato areno-lodoso do "Mar de Dentro" (Ilha do Mel - Maía de Paranaguá - Brasil). Dusenia 5:209-232

Jakobi H, Loyola e Silva J (1962) Two new species of Parastenocaris (Cop. Crust.) from Santa Catarina, Brazil. Proc U S Nat Mus 113: 389-397

Jörger KM, Stoschek T, Migotto AE, Haszprunar G, Neusser TP (2014) 3D-microanatomy of the mesopsammic Pseudovermis salamandrops Marcus, 1953 from Brazil (Nudibranchia, Gastropoda). Mar Biodivers. doi:10.1007/s12526-014-0224-5

Kihara TC, Rocha CEF (2009) Técnicas para estudo taxonômico de copépodes harpacticóides da meiofauna marinha. 1. ed. Porto Alegre: Asterisco, 2009, 300. 94p

Leipniz II, Ferreira F, Leão CJ, du Châtelet EA, Frontalini F (2014) Foraminiferal and testate amoeba diversity, distribution and ecology in transitional environments of the Tramandaí Basin (Rio Grande do Sul, South Brazil). Mar Biodivers. doi:10.1007/s12526-014-0243-2

Lotufo GR, Rocha CEF (1993) Intertidal Interstitial Halicyclops From Brazilian Coast (Copepoda: Cyclopoida). Hydrobiologia 264: $175-184$

Marcus E (1946) Batillipes pennaki, a new marine tardigrade from the North and South American Coast. Comun Zool Mus Hist Nat Montev 2(33):1-3
Marcus E (1947) Turbelários marinhos do Brasil. Bol Fac Filos Ciênc Univ Sao Paulo (Zool) 12:99-215

Marcus E, Du Bois-Reymond ME (1951) Contributions to the Natural History of Brazilian Turbellaria. Comun Zool Mus Hist Nat Montev $3(63): 1-25$

Marcus E, Du Bois-Reymond ME (1954a) The nudibranch Rhodope from South America. Comun Zool Mus Hist Nat Montev 4(68):1-8

Marcus E, Du Bois-Reymond ME (1954b) Über Philinoglossacea und Acochlidiacea. Kiel Meeresforsch 10:215-223

Marcus E, Du Bois-Reymond ME (1955) Sea-hares and side gilled slugs from Brazil. Bol Inst Oceanogr 6:349

Marcus E, Du Bois-Reymond ME (1956) On two sacoglossan slugs from Brazil. Am Mus Novit 1796:1-21

Marcus E, Du Bois-Reymond ME (1957) Turbellaria. Expl Hydrobiol Lacs Kivu Edouard et Albert Res Sci 3(2):27-52

Medeiros LRA (1987) Conhecimento sobre meiobentos no Brasil e relato de um caso da costa sudeste-sul brasileira: Síntese de conhecimentos. Publ Aciesp 54:348-379

Meyl AH (1956) Beiträge zur freilebenden Nematodenfauna Brasiliens. I. Acht neue Nematodenarten aus Überfamilie Dorylaimoidea. Nematologica 1:311-325

Netto SA, Meneghel A (2014) Pulse of marine subsidies: the role of surf diatom Asterionellopsis glacialis accumulations in structuring meiofauna of sandy beaches. Mar Biodivers. doi:10.1007/s12526014-0253-0

Netto SA, Attrill MJ, Warwick RM (1999a) Sublittoral meiofauna and macrofauna of Rocas Atoll (NE Brazil): indirect evidence of a topographically controlled front. Mar Ecol Progr Ser 179: $175-186$

Netto SA, Warwick RM, Attrill MJ (1999b) Meiobenthic and Macrobenthic Community Structure in Carbonate Sediments of Rocas Atoll (North-east, Brazil). Estuar Coast Shelf Sci 48:39-50

Prantoni A, Di Domenico M, Lana PC (2014) A taxonomic overview of marine and estuarine oligochaetes from Brazil. Mar Biodivers. doi: 10.1007/s12526-013-0190-3

Remane A, Siewing R (1953) Microcerbereus delamarei $\mathrm{n}$. sp., ein marine Isopodenart von der Küste Brasiliens. Kiel Meeresforsch 9:280-284

Reygel P, Schockaert E, Janssen T, Artois T (2014) Two new species of Carcharodorhynchus Meixner, 1938 (Platyhelminthes: Rhabdocoela: Schizorhynchidae) from Brazil and Lanzarote. Mar Biodivers. doi:10. 1007/s12526-014-0205-8

Santos PJP, Castel J, Souza-Santos LP (1999) Development time of harpacticoid copepods: some empirical models and implications. J Mar Biol Ass UK 79:1123-1124

Schuster R (1962) Das marine Litoral als Lebensraum terrestricher Kleinarthropoden. Int Rev Ges Hydrobiol 47:359-412

Siewing R (1953) Bodidiellae brasiliensis, ein neuer Amphipode aus dem Küstengrundwasser Brasiliens. Kiel Meeresforsch 9:243-247

Siewing R (1954) Zur Verbeitung von Pisionidens indica Aiyar and Alikunnhi. Kiel Meeresforsch 10:81-83

Sørensen MV (2014) First account of echinoderid kinorhynchs from Brazil, with the description of three new species. Mar Biodivers. doi:10.1007/s12526-013-0181-4

Todaro MA, Rocha CEF (2004) Diversity and distribution of marine Gastrotricha along the northern beaches of the state of São Paulo (Brazil), with description of a new species of Macrodasys (Macrodasyida, Macrodasyidae). J Nat Hist 38:1605-1634

Todaro MA, Rocha CEF (2005) Further data on marine gastrotrichs from the State of São Paulo and the first records from the State of Rio de Janeiro (Brazil). Meiofauna Mar 14:27-31

Venekey V, Gheller PF, Maria TF, Brustolin MC, Kandratavicious N, Vieira DC, Brito S, Souza GS, Fonseca G (2014) The state of the art of Xyalidae (Nematoda, Monhysterida) with reference to the Brazilian records. Mar Biodivers. doi:10.1007/s12526-014-0226-3

Westheide W (1974) Interstitielle Polychaeten aus brasilianischen Sandstränden. Mikrof Meeresbodens 31:1-16 